\section{Determinants of military expenditure in Zimbabwe}

\section{Zachary Tambudzai}

A

lthough by African standards Zimbabwe's military expenditure burden of around 3.8 percent of GDP in 2009 seems modest, it represents a significant increase from the 1.7 percent reported in 2004. It is unlikely to be amenable to econometric analysis, given Zimbabwe's turbulent recent history and the general lack of transparency there. Important influences on spending are likely imbedded in the beliefs and attitudes of decisionmakers and, as in most other developing countries, it is likely to be an extremely opaque process, with many off-budget sources of income. Certainly there is evidence to suggest that in Africa security-related outlays are frequently deliberately included in nonmilitary budgets, with weapons purchases often funded from off-budget and extra-budgetary sources. ${ }^{1}$

This article studies influences on and identifies various types of extra-budgetary and hidden channels of funding military activities in Zimbabwe. The aim is to obtain insight into the military budgetary process and to explore institutionalized means for controlling, monitoring, and auditing the country's military expenditure. Given its colonial history, and that it shares certain institutional and governance characteristics of other southern African countires, Zimbabwe provides a particularly interesting case.

The article briefly reviews research on the military budgetary process in Africa before outlining the research method used to investigate determinants of military expenditure in Zimbabwe. It then examines factors that influenced budget allocations to the security forces in Zimbabwe up to 2009.

\section{Military budgeting in Africa}

Studies of the determinants of military expenditure are numerous, but those focusing on Africa are limited in number. Most employ econometric analyses of country or cross-country data to examine the impact of economic and strategic factors. While they yield with some interesting results, they fail to explain the processes involved. To develop a better understanding of the allocation of public spending to the military, an analysis of the underlying motivating factors is needed. These include geostrategic considerations, budgetary politics, the behavior of arms suppliers, enabling factors, such as linkages between interest groups, and underlying factors, such as military pressure groups, and the belief that military expenditure results in greater national security, status, and pride. As one analyst observed, a "highly non-transparent military sector” is a breeding ground for off-budget expenditure and corruption, which can undermine a security force's operational efficiency. ${ }^{2}$

A culture of secrecy is a common feature in the military sector in Africa, and the ruling elite in most states regard the military as a special institution. Indeed, studies of military budgeting have found that for most countries, there is no prescribed military budgeting process. For example, one study of eight African countries (Ethiopia,

Ghana, Kenya, Mali, Mozambique, Nigeria, Sierra Leone, and South Africa), found that procedures for budgeting for the military were not followed in practice. Where there is a documented formal process, it is typically ignored and in most cases budgets are determined by a small faction close to the executive in an informal way, with little relation to a military plan or goal. The general public and professionals in most African states did not debate or participate in the formulation of security policy and the role of parliament was limited by the lack of experts and knowledge about the military sector. Audit reports rarely included corrupt practices in the defense ministries and were never critical of off-budget spending. Off-budget spending was evident in many military institutions and there was very little transparency and lack of scrutiny in military budgeting. ${ }^{3}$

Apart from the normal budget allocations there are other potential military revenue sources, including income from military business activity, special funds from nonmilitary parastatals, war levies, foreign military assistance, and criminal activities. United Nations peacekeeping operations, in which the participating countries and their soldiers are rewarded were also an important source of funds. The military were also involved in business activities to supplement their inadequate salaries and finance daily activities. Foreign exchange revenues from resource extraction and credit from friendly overseas governments for the purchase of military equipment can also be of importance. ${ }^{4}$

In attempting to understand the determinants of military expenditure in a country that has had the turbulent history of Zimbabwe, one would expect the culture, underlying processes, and institutional factors to play an important if not dominant role. To analyze them, it is necessary to look beyond the reported figures and delve into the underlying motivations and drivers, using qualitative rather than a quantitative data.

\section{Research procedure}

For this study, informal interviews were carried out with six categories of respondents 
from government bureaus, the security sector, parliamentarians, opposition parties, civil society (including the media), and relevant academics. In line with Harris research for South Africa, thirteen research questions (presented in the appendix) were used where possible. Given the volatile political environment in which the research was conducted, it was difficult to fulfil the planned sample size of 24 participants, but efforts were made to interact with individuals from all target groups and a response rate of 67 percent was achieved, with an average of 3 interviewees per category. When interviews were not possible, direct informal interactions with informants, telephone interviews, and email were used to elicit responses.

Information was also collected from secondary sources such as documents from various public and private archives in Zimbabwe and online government and private archival sources for the period 2005 to 2009. Internet searches provided information on more recent developments from online sources including newspapers (both private and government owned), speeches (by ministers, senior army officers, members of parliament, and senior civil servants), and nongovernmental organizations' web sites (e.g., Zimbabwe Democracy Trust, Global Integrity, and International Crisis Group). Journal articles and books written on the Zimbabwean Defence Forces (ZDF) by various military specialists provided more detail. ${ }^{5}$

Data analysis and processing involved the use of Nvivo 2, a qualitative data analysis software package, to assist in coding and categorizing data into various factors that influence decisionmakers when allocating resources to the military. Checking for consistency of views from interviews (triangulation) was achieved by examining and comparing findings from the six different informant categories, and comparing interview data with information collected from documents. The analysis first involved generating themes from the codes and categories identified in the textual data; second, producing a general description of the responses from informants in line with the themes generated; and third, producing a description of data obtained from various documentary sources. The secondary sources acted as "confirmatory data collection-deepening insights into and confirming patterns that seem to have appeared." 6

Drivers of military spending

Three major themes on influences on military expenditure were identified from the responses. First, high levels of military spending were justified by beliefs and attitudes regarding external threats, regime change threats, and security. Second, military spending was promoted by the relationship between the ruling elite and the military. Third, the budgetary process was characterized by an overall lack of oversight. While markedly different responses were received from the different informants, in general they saw local, regional, and international political and security imperatives as drivers of the level and trend of Zimbabwe's military expenditure. The influences on military expenditure allocations as obtained from the informal interviews were consistent with the data obtained from the documentary sources.

Perceived threats: external and internal

Most government and military officials interviewed suggested four major justifications for the allocation of funds to the military sector: state security, regime change or (external) threats, fulfilling peacekeeping duties, and the influence of regional wars or internal political instability.

Informants from the other four groups (parliament, civil society, opposition, and academics) saw allocations being driven by the government's desire to curry favor with the military, the desire to maintain regional superiority, a sense of political insecurity and re-election strategy, and rent-seeking and corruption. Primary sources were consistent with government documents identifying the reasons for financing the military as the need to fulfill its constitutional role of providing national defense, the volatile and unpredictable security environment and external threats, the need for training of military personnel, regional cooperation and international peacekeeping operations, and the re-equipment and modernization program.

Government officials interviewed believed that the West pursued a regime change agenda for Zimbabwe, so the government of Zimbabwe needed to step up military training and military equipment acquisition to increase national security. Some informants within the military emphasized the influence of a necessary renewal program, to acquire new weapons following the arms embargo imposed by the West in 2002. The then-defense minister, Dr. Sekeramayi, argued that " $[\mathrm{m}]$ ilitary preparedness should always be top priority, even during peacetime. While there may be no direct military threats to Zimbabwe today, there may be one tomorrow.” To achieve this, in 2006 the Ministry of Defence (MoD) revealed that the Zimbabwe Defence Forces had signed major contracts with Chinese companies like NORINCO, CATIC, and Polytechnologies. Funding for the renewal program also came directly from the Reserve Bank of Zimbabwe (RBZ). ${ }^{7}$

Up until 1993, the government used apartheid threats to justify high spending. Currently, they point to the threat of invasion by the United States and the United Kingdom. Some academics argue that the paranoia of re-colonization and invasion is influenced by the position taken by the West in classifying Zimbabwe together with rogue states like Iran and North Korea. Senior army officials expressed similar sentiments at graduation parades for newly trained soldiers. In 2006 and 2007, senior 
army and air force commanders took turns to highlight the threats posed by the West to Zimbabwe and urged the soldiers to defend the country's independence. ${ }^{8}$

At various forums and speeches, President Mugabe has accused Britain and the white farmers of funding attempts at regime change in Zimbabwe. This was echoed by senior defense officials and commanders, who asserted that the pattern of expenditure is influenced by "the dynamic, volatile and unpredictable nature of the country's security environment.” Other respondents outside government and the military establishment, however, believe the regime change argument to be a smoke screen, meant to hide the use of patronage and to ensure regime security. They argue that the state has bought the loyalty of the defense forces through salary hikes and nonpecuniary packages (farms, cars) and see the ruling party-military alliance as a way of maintaining political power and satisfying business and political rent-seeking interests. ${ }^{9}$

Three government and military officials interviewed indicated that there is a military threat from the West toward Zimbabwe. This is corroborated, for instance, by Brigadier General Trust Mugoba's speech in 2006 where he noted that the government had reduced army personnel by 25 percent because of “a lack of external threats and had channeled the money into social development instead.” To some extent this gives credence to the assertion by civil society and opposition groups that the external threats argument is not real. ${ }^{10}$

The arms embargo imposed by the West is believed to have limited the military capability of the ZDF. This forced the ZANU-PF (the ruling party) regime to look for other sources of arms as well as other methods of financing the purchases, given the worsening economic conditions. In addition to normal budget allocations, the government relied on barter trade to acquire ammunition, equipment, and planes. Mugabe turned to Asia and to the Middle East and used mining and farming concessions to get more arms. China took the bulk of Zimbabwe's tobacco, diamonds, and gold in exchange for agricultural equipment and military hardware. In 2004, the Parliamentary Committee on Defence and Home Affairs was informed by the defense ministry that arms acquisitions were necessitated by an arms and spares embargo on Zimbabwe. $^{11}$

Apart from the provision of national security by a well-trained force, there was also an element of trying to retain national pride and status achieved through participation in peacekeeping and military interventions in crises in Angola, the Democratic Republic of Congo, Lesotho, Mozambique, Rwanda, and Somalia. Zimbabwe also participated in peacekeeping operations in East Timor, Kosovo, and Sierra Leone, and more recently in Sudan's Darfur region. Zimbabwe also provides training infrastructure for the Southern Africa Development Community (SADC) to instruct peacekeepers and offer security training courses. Peacekeeping duties are an opportunity to boost the funds available to the ZDF. The proceeds from United Nations peacekeeping missions were used to purchase vehicles from Japan. There has, however, been a shift in Zimbabwe's defense policy since 2000, away from the idea of regional collaborative security of the 1990s to the preservation of the ZANU-PF party and government. Whether the external threats to national security are real or not, they seem to have a bearing on the extent of the resources allocated to national defense in Zimbabwe. ${ }^{12}$

The relationship between the military and the ruling elite

As expected, the research findings indicate that the ruling party (i.e., ZANU-PF) used patronage among security chiefs to retain political power. It manipulated the defense budgetary process to ensure that parliament ratified defense allocations without considering trade-offs with other departments. In addition to the budgetary allocation, a much larger amount was hidden in unallocated reserves by the Ministry of Finance (MoF) and, more recently, parliament has been called upon by the executive to condone unauthorized spending by the military, facilitated by the RBZ through quasi-fiscal policies. ${ }^{13}$

There is little external scrutiny of military budgets as military-related national pressure groups have had little effect and multilateral donor organizations have had no direct influence since 1999. In contrast, the suppliers of military-related goods have had considerable influence on the size of the defense budget through their connections to the military leadership and the ruling party politicians. The military incursion in the DRC in 1998 had the backing of a number of Zimbabwean entrepreneurs, who have relations with the army and senior politicians. ${ }^{14}$

Military and intelligence services also influence the size of the security budget through the Joint Operations Command (JOC), the ruling party, and the presidency. Human Rights Watch Zimbabwe has argued that the military defends Mugabe because they are corrupt and that the JOC members “.... have dirty hands. They’ve enriched themselves and want to hang on to what they have and avoid charges of corruption.” For instance, a company owned by the Zimbabwe Defence Forces commander's wife, ZimSafe, won some contracts to supply reflective clothing. While Mr. Muchakazi, a procurement specialist with the MoD acknowledged this, he refuted allegations of corruption in the procurement process. Other MoD officials acknowledged that the tendering process led to higher than normal prices and expressed reservations about the effectiveness of the indigenization policy on army procurement. For instance, the permanent secretary in the MoD said “... middleman ended up profiteering at the expense of taxpayers. There is a political element in these so-called middlemen and indigenous companies. If we [the defense ministry] go to established companies for our supplies, we achieve our goals and end up saving.”"15

Zimbabwe does not have an arms industry per se but it does produce ammunition for small arms. Zimbabwe Defence Industry (ZDI), a government-owned company formed in 1984, manufactures small arms and exports ammunition mainly to African countries. Comments in interviews suggested that the operations of ZDI are not transparent and not even reported in parliament. "The culture of secrecy and silence 
which is characteristic of the present ZDI operations is out of step with current international trends and democratic practice.”16

Expenditure on military equipment also appears to be fueled by elections. In 2005, military sources said, “[o]ur army has received the equipment as part of a deal to fully equip it ahead of the March parliamentary elections. Mugabe would want the army to be totally prepared in advance of the 2005 parliamentary elections to retain him in power."17

Militarization of state institutions emanates from Zimbabwe's political and liberation history, resulting in a brutal political culture. As Rupiya observed, the use of "the military approach” in order to solve the country’s problems “... has not moved out of the revolutionary war context," illustrating the special role the military plays in the state. To this can be added the rent-seeking behavior of both the army and ZANU-PF government that leads to collective behavior to maintain or increase military spending. A military chief's stay in power is guaranteed by the ruling party, and the party's continuous hold on power is guaranteed by the military forces. The armed forces are co-opted into civilian duties and so their influence in budget allocation increases and there is no real objective debate. ${ }^{18}$

The secretary general of the Movement for Democratic Change (MDC) is in no doubt about the reasons behind the lack of oversight in the budgetary process. Commenting on the 2007 Supplementary Budget, Biti wrote: "Stripped [to] its bare bones the supplementary budget betrays ... the power retention agenda in which the State resources will be spend without reason or limit purely for the purposes of maintaining and reproducing power. One finds that the amounts allocated to the President's Office, the Ministry of Defence and the Ministry of Home Affairs, is a staggering ... 33 percent of the supplementary budget.” The main purpose of the military budget is power retention by the ZANU-PF government. Biti also wrote, “... it is a State that is fiercely loyal to one value and one value alone; the power retention matrix."19

Most military analysts agree with Biti's sentiments and analysis that security forces are there to defend the regime in power rather than the country. So far, ZANUPF has obtained favorable political results from the terror instilled by the armed forces and the veterans of the liberation war. This has encouraged politicians and government to cultivate an excellent relationship with the defense forces, especially the commanders. This is the reason why in return for a good power retention job, the army always gets monetary and nonmonetary benefits. ${ }^{20}$

Chitiyo and Rupiya summarised ZANU-PF's survival strategy as a military operation, the so-called Third Chimurenga. They noted that, "[b]elieving that it [ZANU-PF] faced a 'total onslaught' from internal and external opponents who wished to hijack the gains of the liberation war in modern Zimbabwe, the state responded with its own 'total offensive' (legal, political, cultural, economic and military) to ensure state survival and to preserve the gains of land redistribution exercise.” Ndlovu-Gatsheni concurred with this assessment when he wrote: “These recent developments testify to the trend towards militarism in politics.” He argued that ZANU-PF has used the army in a "political power game. It seems they [the army] see themselves as hired to protect the regime in power rather than the population of Zimbabwe.” Rupiya also observed that "[i]n the newfound relationship, the distance between party and government was collapsed and by extension, the professional standing of the military in its national symbolism disappeared. Instead, the security organs have assumed partisan roles and functions in support of the ruling party ...”21

Ndlovu-Gatsheni also noted that ZANU-PF has succeeded in politicizing the army and the police. Zimbabwean defense forces commanders have repeatedly vowed not to allow anyone who did not fight in Zimbabwe's liberation war to take power as president of the country. "To keep the army on his side, President Mugabe has awarded soldiers substantial salary and allowance increases. Officers in the army have also been given a larger slice of seized white farmlands." The comments and statements from academics and military researchers show how important is the military to the ZANU-PF regime and how they are in the driving seat. This removes all superordinate rationality from the process of allocating resources to the military (i.e., "rationality" is restricted to the inside deal between military and ZANU-PF). With the bulk of decisionmakers even in cabinet having a military/security background, who can oppose a flawed budget from the Minister of Defence? ${ }^{22}$

The nontransparent military budgetary process

The informants made it clear that the Zimbabwe military gets special treatment in resource allocation. The military's demands are met without justification by the governing party. Ministry of Defence budget rules are not always respected, particularly with requests for additional funding and expenditure where, contrary to normal budget principles, the executive does not normally consult parliament. Most informants (63 percent) believe that in Zimbabwe, expenditure on health and education should be accorded special attention instead of spending on defense, confirming the views expressed in some secondary sources, which argue for a reprioritization of government spending to deal with economic and social problems. ${ }^{23}$

Hearings by the Parliamentary Committee on Defence and Home Affairs revealed that the cabinet makes military decisions without consultation with parliament, reinforcing the International Crisis Group (2000) report that ZDF intervention in the DRC had been a unilateral decision and "was done with little or no consultation with Parliament ... and until August 2000, the Zimbabwean public was provided little information about the engagement-including what it cost and casualties incurred." A member of the Defence Committee, Kasukuwere, “... queried the manner in which the purchase of military equipment had by-passed the State Procurement Board, a move he said might result in the army buying equipment which may be expensive, but having a short life span.” The lack of transparency and the flouting of procedures are prone to breeding corrupt practices that seem to be rampant in military circles. 
Makumbe also noted that corruption in Zimbabwe is rife because there is "currently no agency responsible for monitoring conflicts of interest among public servants who make decisions on matters of state procurement and the awarding of tenders ...” Henk and Rupiya also revealed the weakness in accountability and reported that Zimbabwe's Comptroller and Auditor-General had repeatedly called attention to irregularities in military spending, with billions of dollars unaccounted for and little indication of government interest in investigating wrongdoing or correcting the abuse in ministries. ${ }^{24}$

Contrary to McNutt's assertion that governments are there to be manipulated, in Zimbabwe it seems the regime had a fair share of manipulating the military to its advantage. Two-thirds of informants noted that there is no serious oversight over military spending and that normal budgetary rules and procedures are not being followed. In practice, there appears to be no sense of trade-offs in resource allocation by the executive. A government official acknowledged that " $[t]$ he objectives as stated in the defense policy are now different. The [military] budget is designed to serve partisan interest. Currently, conditions in government simply call for a stronger army and heavily armed uniformed force to coerce citizens to obey the law and vote for the current government to stay in power. There is no civility in the decisionmaking process since everything sounds arbitrary and biased."25

Government documents show that the budgetary process in the military is the same as in the other government ministries and departments. The budgetary process has many discrete phases, the first stage being pre-budget meetings between January and March of every year. Parliament is involved in the budgetary process at the formulation stage through participation in a pre-budget seminar. However, Mnangagwa emphasised that the national budget in Zimbabwe is guided by nationalist principles as well as by patriotism. ${ }^{26}$

The official role of the parliament in military budgeting and management is to regulate and ensure accountability. "[T]he ZDF is subject to the security and administration of regulatory parliamentary and security committees. These include Budget, Public Accounts and Security committees, which censor the defense budget, scrutinize defense expenditure and monitor the activities of the defense forces, respectively." In addition, there is the Comptroller and Auditor-General, an independent officer accountable to parliament who each financial year, examines, audits, and reports on public funds property in terms of the Constitution and the Audit and Exchequer Act. However, for almost two decades, parliament has had no say in military matters. Furthermore, since 2003, the defense ministry has benefited from the RBZ's quasi-fiscal policies, not included in the national budget. In the case of citizens' participation in budget formulation, research by Global Integrity found that " $[\mathrm{t}]$ he sentiments of citizens are generally not respected, feared or listened to ... So though the citizens murmured disapproval at the largest budget allocation going to defence in a time of peace, nothing was done about it."27

These findings show that the military budgetary process is mainly a political exercise, with institutions of democracy playing a secondary role as the ruling elite can raise the military budget levels without even consulting parliament. Military purchases only come into the public domain or parliament well after deals have been concluded. The rules guiding the fiscal process are there, but ZANU-PF/military interests determine the military expenditure levels. Armament procurement as well as military interventions are deemed to be executive decisions.

\section{Conclusion}

Integrating the findings from the informal interviews and document analysis gives a view of the important institutions and processes involved in the allocation of resources to the military in Zimbabwe. Although the military budget is presented in the national budget, the final figure rests with the ruling elite, especially the presidency and the security arms of government. Military expenditure fits the aspirations of the ruling party, implying that national security is secondary to regime security. Military leaders are presented as a subset of ZANU-PF because of the close association (alliance) between the two, and the formation of the JOC shows just how influential the army has become in resource allocation decisions. Documentary evidence shows that the opposition parties believe that ZANU-PF and the military determine the levels of military expenditure. As MDC spokesperson Nelson Chamisa once said, "[i]f you look at key institutions, the army is calling the shots. Even Mugabe's campaign is being carried out by the army."28

This article has provided a qualitative analysis of the determinants of military expenditure in Zimbabwe. It complements econometric studies by illustrating the influence of internal historical and political dynamics on top of external threats and economic factors. The importance of the domestic-political dynamics in military expenditure allocation decisionmaking has been demonstrated, with regime security and rent-seeking/elite corruption being important factors in increasing military expenditure allocations. Other factors that influence allocations are the lack of serious oversight and accountability, the liberation ideology and mentality of the Mugabe regime, and the regime change paranoia caused by a Western arms embargo and other selective sanctions.

While Zimbabwe is a very specific case, the article does illustrate the potential importance of qualitative factors in understanding the determination of military expenditure, especially in Africa where similar conditions obtain.

\section{Notes}

Zachary Tambudzai is a lecturer in economics at the School of Economics and Finance, University of KwaZulu-Natal, Pietermaritzburg, South Africa. He may be reached at <tambudzai@ukzn.ac.za>. 
1. Previous research includes: Tambudzai (2006a),Tambudzai (2006b),Tambudzai (2010). Off-budget sources: Hendrickson and Ball (2002); Henk and Rupiya (2001). Extremely opaque: Gyimah-Brempong (2002). Military expenditure burden: Index Mundi (2009).

2. Underlying motivating factors: Harris (2002a). Quote: Ball (2002).

3. Special institution: Harris (2005); Omitoogun (2006). Eight countries: Omitoogun and Hutchful (2006). No prescribed military budgetary process: Henk and Rupiya (2001); Omitoogun (2006); and Omitoogun and Hutchful (2006). No debate or participation: Henk and Rupiya, (2001). Audit reports: Omitoogun and Hutchful (2006).

4. Off-budget spending: Hendrickson and Ball (2002). UN peacekeeping rewards: (Henk and Rupiya, 2001).

5. Harris: Harris (2002a; 2004a; 2004b; 2010).

6. “Confirmatory data ...”: Patton (2002, p. 436).

7. One informant noted that "the military is the modern organization of the security mechanism hence the expenditure is ... justified on the need to make sure that the military is well-equipped to defend national interests.” Defense top priority: [Herald] 2005. RBZ funded purchases: [Herald] 2006.

8. Apartheid threats: Chitiyo and Rupiya (2005). West paranoia: A respondent from academia had this to say: "The natural paranoia of the government is, I think, exacerbated by the position of its perceived enemies ... the West. There is an unhealthy relationship, which probably allows the government to justify its military expenditure. That such countries as Iraq and Afghanistan have been invaded, and Zimbabwe (was) placed by U.S. Secretary of State Condoleezza Rice, alongside Iran and North Korea as part of the 'axis of evil' probably raises their fears and therefore allows them to justify their expenditure.” Western threats: In 2006, the Air Vice Marshal Elson Moyo “... urged the graduands to defend the country’s sovereignty saying Zimbabwe was under Western siege. 'We have to defend at all cost our nation and its territorial integrity”': [ZDF News] 2006b. In 2007, General Sibanda said: "Your passing out today comes at a time when the country is facing numerous challenges, as a result of sanctions imposed on Zimbabwe and the regime change agenda of the British and Americans ...”: [ZDF News] 2007.
9. Funding regime change: For instance, in 2007 Mugabe said: "There is an orchestrated, much wider and carefully planned regime change plot by internal and external enemy forces with plenty of funding from some commercial farmers and British organizations ...”: [Zimbabwean] 2007. Dynamic and volatile: [The Herald] 2005.

10. No external threats: Mafunda (2006).

11. Limited capability, barter trade, China: Peta ( 2005), Dzamara (2007). Arms and spares embargo: [Newzimbabwe] 2004 .

12. Peacekeeping operations: [ZDF News] 2006a. Preservation of power: Chitiyo and Rupiya (2005, p. 351). Training infrastructure: Chitiyo and Rupiya (2005, p. 351).

13. Parliament approves a smaller figure: An informant, who was a member of parliament and a member of the Budget Portfolio Committee.

14. Military-related groups: An informant from civil society. Backing from the business sector: Informant from government_- "Companies of those related to army chiefs are given preference as suppliers of military needs. For example, the wife of the armed forces chief, (is) the owner of a company called ZimSafe, which supplies reflective clothing to the security forces. This is a clear conflict of interest and that one cannot even imagine how that relationship affects military expenditure but that is just a single example. Another case is the ZDI [Zimbabwe Defence Industry]. The proceeds from the industry have not been accounted for and its activities are not reported to parliament.”

15. Corrupt JOC: Lindow (2008, p.3). Zanu-PF business deals: [Zimbabwean] 2007. Mr. Muchakazi: [ZWNEWS] 2006.

16. Small arms industry: Nkiwane (1999). Culture of secrecy: Mlambo (1999).

\section{For elections: [ZWNEWS] 2005.}

18. Militarization: Rupiya (2003). Brutal political culture: Ndlovu-Gatsheni (2003b). Military approach: Rupiya (2003, pp. 251-252). Stay in power: senior opposition politician.

19. Lack of oversight: Biti (2007a). Power retention matrix: Biti (2007b).

20. Defending the regime in power: Rupiya and Chitiyo (2005); Rupiya (2007; 2008); Ndlovu-Gatsheni, (2003a; 2003b; 2006). 
(C) www.epsjournal.org.uk - Vol. 6, No. 2 (2011)

21. Zanu PF survival strategy: Chitiyo and Rupiya (2005, p. 359). Militarism in politics: Ndlovu-Gatsheni (2003a, pp. 28-29). Professional standing of the army: Rupiya (2008, p. 1).

22. Politicizing the army: Ndlovu-Gatsheni (2003a, pp. 28-29). Soldiers awarded substantial salaries: [ZWNEWS] 2005.

23. Informants: Parliamentarians, government officials, opposition members. Special attention: Ndlovu-Gatsheni (2003b, p. 130) and Guma (2007).

24. No consultation: International Crisis Group (2000, p. 6). MP Kasukuwere: [Newzimbabwe] 2004. Corruption in procurement: Makumbe (2004, p. 3). Accountability: Henk and Rupiya (2001, pp. 19-21). Defense forces failed to account for billions: Manyukwe (2007).

\section{McNutt: McNutt (1996, p. 140).}

26. Government documents: $\operatorname{MoF}(\mathrm{n} / \mathrm{d})$. Budget guided by nationalist principles: Mnangagwa (2004).

27. Regulatory parliamentary and security committees: Chitiyo and Rupiya (2005, p. 350). Quasi-fiscal policies: Murerwa (2006, pp. 28, 40). Sentiments of citizens: Global Integrity (2004, question 33).

28. Lindow (2008, p. 2).

\section{References}

Ball, N. 2002. "Managing the Military Budgetary Process: Integrating the Defence Sector into Government-wide Processes.” Mimeo. Washington, D.C.: Center for International Policy.

Biti, T. 2007a. “The Supplementary Budget: The House has Fallen.” Movement for Democratic Change. <http://www.mdc.co. zw/pressbody.asp?pressid=2> [accessed 30 November 2007].

Biti, T. 2007b. “2008 Budget: Playing Blind Man’s Bluff with the Economy.” Newzimbabwe. 30 November 2007. <http://www. newzimbabwe.com/pages/ inflation174.17229.html> [accessed 30 November 2007]

Chitiyo, K. And M. Rupiya. 2005. “Tracking Zimbabwe’s Political History: The Zimbabwe Defence Force from 1980-2005,” pp. 331-363 in M. Rupiya, ed Evolutions and Revolutions: A Contemporary History of Militaries in Southern Africa. Pretoria: Institute of Security Studies.

Dzamara, I. 2007. “China, Israel Delivers Weapons.” The Zimbabwean. 30 October
2007. <www.thezimbabwean.co.uk/index.php?view=article\&catid=31\% Atop+zimbabwe+stories\&id=9684\%3AChina\%2c+deliver+weapons+\&option $=$ com_content\&Itemid $=66>$ [accessed 31October 2007].

Global Integrity. 2004. “Global Integrity Report 2004: Zimbabwe: Integrity Scorecard.” <http://www.globalintegrity.org/r eports/2004/2004/scorese8fc. html?cc=zw\&intQuestionID =92\&catID1=3\&catID2=2> [accessed 20 May 2005].

Guma, L. 2007. "Security and Defence Gobble up Half the Budget as Elections Approach.” SW Radio Africa Zimbabwe News. 7 September 2007. <http://www.swradioafrica.com/news070907/ budget070907.htm> [accessed 7 September 2007].

Gyimah-Brempong, K. 2002. "Researching Military Expenditures in Africa: Findings and Lessons from Researchers.” Paper. Workshop on Military Budgeting in African Countries. Accra, Ghana, 25-26 February.

Harris, G. 2002a. "Military Expenditure and Economic Development in Asia during the 1990s,” pp. 71-98 in J. Brauer and J.P. Dunne, eds. Arming the South: The Economics of Military Expenditure, Arms Production and Arms Trade in Developing Countries. Houndamills, UK: Palgrave.

Harris, G. 2002b. “The Irrationality of South Africa’s Military Expenditure.” African Security Review. Vol.11, No. 2, pp. 75-86.

Harris, G. 2004a. Military expenditure in Sub-Saharan Africa: Why Guns Cost more than Butter. Johannesburg: The Free Market Foundation.

Harris, G. 2004b. "Security Sector Reform and Military Budgeting: A Review of Issues.” Mimeo. Southern Africa Military Expenditure Project Discussion Paper 4, School of Economics and Finance, University of KwaZulu Natal.

Harris, G. 2005. “Towards more Rational Military Budget Formation in Sub-Saharan Africa: The Relevance of Security Sector Reform.” Strategic Review for Southern Africa. Vol. 27, No.1, pp.66-88.

Harris, G. 2010. "What Drives Military Expenditure? A South African Study." Journal of Interdisciplinary Economics. Vol.21, No.2, pp. 197-209.

Hendrickson, D. and N. Ball. 2002. “Off-Budget Military Expenditure and Revenue: Issues and Policy Perspectives for Donors.” CSDG Occasional Paper 1. London: International Policy Institute, King's College.

Henk, D.W. and M.R. Rupiya. 2001. "Funding Defense: Challenges of Buying Military Capability in Sub-Saharan Africa.” Strategic Studies Institute. <http://www.strategicstudiesinstitute.army.mil/pdffiles/PUB198.pdf> [accessed 13 May 2005].

[Herald] 2005. "Defence, Security Not Cheap Commodities." The Herald [Zimbabwe]. 4 February 2005. <http://www.zimbabwesituation.com/feb6a_2005. html\#link3> [accessed 23 February 2005].

[Herald] 2006. “Zim Procures Six Trainer Aircraft.” The Herald [Zimbabwe]. 23 August 2006.

Index Mundi. 2009. “Zimbabwe-Military Expenditures-Percent of GDP.” Index 
Mundi. <http://www.indexmundi.com/g/g.aspx?v=132\&c=zi\&l=en> [accessed 31 August 2009].

[ICG] International Crisis Group. 2000. “Zimbabwe: Three Months after the Elections.” Africa Briefing Paper. September 26. Harare/Brussels: ICG.

Kraan, D.-J. 1996. Budgetary Decisions: A Public Choice Approach. Cambridge: Cambridge University Press.

Leonard, T. 2005. "Mugabe Turns to Military to Ensure Victory.” Zimbabwesituation <http://www.zimbabwesituation.com/feb27_2005.html\#link3> [accessed 26 February 2005].

Lindow, M. 2008. “Zimbabwe under Military Rule?” <www.time.com/time/world/ article/0,8599,1813656,00.html > [29 October 2008].

Mafunda, K. 2006. “Army Cut Down by 25 Percent.” Financial Gazette. 9 February 2008. <http://www.zimbabwesituation.com/feb9a_2006.html\#Z4> [accessed 10 February 2006].

Makumbe, J. 2004. “Integrity Assessment-Zimbabwe,” pp. 2-5 in Center for Global Integrity, ed. Global Integrity: An Investigative Report Tracking Corruption, Openness and Accountability in 25 Countries. Washington D.C: Center for Global Integrity.

Manyukwe, C. 2007. “Armed Forces Fail to Account for Billions.” Financial Gazette. 19 October 2007. <www.fingaz.co.zw/story .aspx?stid=1473> [accessed 19 October 2007].

McNutt, P.A. 1996. The Economics of Public Choice. Cheltenham, UK: Elgar.

[MoF] Ministry of Finance. N/d. "The National Budgetary Cycle." Harare: Government of Zimbabwe.

Mlambo, N. 1998. “The Zimbabwe Defence Industry, 1980-1995.” SADCI Defence Digest. Working Paper No. 2. < www.ccrweb.ccr.uct.ac.za/> [accessed 1 May 2005].

Mlambo, N. 1999. "Small Arms, Regional Security and Economic Development.” Southern African Economist. Vol.13, No.3, pp. 58-60.

Mnangagwa, E.D. 2004. "Speech at the 2004 Pre-budget Seminar.” Holiday Inn, Mutare, Zimbabwe. 15-18 October 2004. Parliament of Zimbabwe.

Murerwa, H.M. 2006. “The 2007 National Budget Statement.” Harare: Government Printers.

Ndlovu-Gathseni, S.J. 2003. "The Post-colonial State and Matabeleland: Regional Perceptions of Civil-Military Relations, 1980-2002,” pp.17-38 in R. Williams and D. Abrahams, eds. Ourselves to Know: Civil-Military Relations and Defence Transformation in Southern Africa. Pretoria: Institute of Security Studies.

Ndlovu-Gatsheni, S.J. 2003. "Dynamics of the Zimbabwe Crisis in the 21st Century." African Journal of Conflict Resolution. Vol. 3, No.1. pp. 99-134.

Ndlovu-Gatsheni. S.J. 2006. "Nationalist-Military Alliance and the Fate of Democracy in Zimbabwe.” African Journal of Conflict Resolution. Vol. 6, No.1, pp. 49-80.
[Newzimbabwe] 2004. "Parliament Seeks Clarity on Zim’s US\$200m Jet Order." Newzimbabwe. 6 June 2004. <http://www.zimbabwesituation.com/jun22a_2004. html\#link6> [accessed 24 June 2005].

Nkiwane, T.C. 1999. "Small Arms Flow in Zimbabwe.” Monograph No. 34. Weapons Flow in Zimbabwe, Mozambique and Swaziland. Africa-talk $<$ www.africa-talk.com/forums/lofiversion/index.php/t192.html> [accessed 1 May 2005].

Omitoogun, W. 2003a. "Military Expenditure Data in Africa: A Survey of Cameroon, Ethiopia, Ghana, Kenya, Nigeria and Uganda.” SIPRI Research Report No.17. Oxford: Oxford University Press.

Omitoogun, W. 2003b. “The Process of Budgeting for the Military Sector in Africa," pp. 261-278 in SIPRI Yearbook 2003. Oxford: Oxford University Press.

Omitoogun W. and E. Hutchful, eds. 2006. Budgeting for the Military Sector in Africa: The Processes and Mechanisms of Control. Oxford: Oxford University Press.

Patton, M.Q. 2002. Qualitative Research and Evaluation Methods. 3rd ed. Thousands Oaks, London, New Delhi: Sage Publications.

Peta, B. 2005. "Arms Deal Raises Fears of Coup if Mugabe Loses Vote." Independent(UK) < http://www.zimbabwesituation.com/feb24a_2005.html\#link6> [accessed 26 February 2005].

Rupiya, M. 2003. “Civil Military Relations in Zimbabwe: Is there a Threat?” in R. Williams and D.Abraham eds. Ourselves to Know: Civil-Military Relations and Defence Transformation in Southern Africa. Pretoria: Institute of Security Studies.

Rupiya, M. 2008. "A Review of the Aftermath of the Zimbabwe Elections 2008 and the Need for SSR.” SRRONLINE English Issue 24: May 2008 $<$ www.ssronline.org/newsletter_story.cfm?id=179\&type=1 $>$ [accessed 20 May 2008].

Rupiya, M. 2007. “The Military Question.” Mail and Guardian [South Africa] April 2007. <www.mg.co.za/articlePage.aspx?articleid=305814\&area=/supzim0407 _home/supzim0407_content/> [accessed 29 May 2008].

Tambudzai, Z. 2005. “Zimbabwe's Military Expenditures: A Study from the Comparative SADC Perspective, 1980-2003.” Africana Bulletin. Vol. 53, pp.135-167.

Tambudzai, Z. 2006a. "Determinants of Zimbabwe’s Military Expenditure, 1980-2003.” Journal of Development Perspectives. Vol. 2, No. 1, pp.103-120.

Tambudzai, Z. 2006b. "Military Expenditure Determinants in Southern Africa, 1996-2005: A Cross-section and Panel Data Analysis.” Mimeo. School of Economics and Finance, Discussion Paper Series: No. 61. University of KwaZulu Natal: Durban.

Tambudzai, Z. 2010. “Determinants of Military Expenditure in Zimbabwe.” Ph.D. thesis. Durban, South Africa: University of KwaZulu-Natal.

[Zimbabwean] 2007. “Zim Troops for DRC.” The Zimbabwean. 31 October 2007. 
$<$ http://www.thezimbabwean.co.uk/index.php?view=article\&catid= 31\%3Atop $+\mathrm{zimbabwe}+\mathrm{s}$ tori es \& id $=9663 \% 3 \mathrm{~A} \mathrm{Zi} \mathrm{m} \mathrm{+} \mathrm{troops} \mathrm{+} \mathrm{for} \mathrm{+}$ DRC\%3F\&option=com_content\&Itemid=66> [accessed 2 November 2007].

Thomas, D.R. 2003. “A General Inductive Approach for Qualitative Data Analysis.” Ph.D. thesis. Aukland: University of Auckland.

[ZDF News] 2006a. “Special Forces Mark Anniversaries.” ZDF News. 6 November 2006. <http://www.zimbabwe defence.com/News_SF_Anniversary.html> [accessed 6 March 2007].

[ZDF News ] 2006b. “AFZ Trains Female Ceremonial Drill Instructors.” ZDF News. 24 June 2006. <http://www.zimbabwe defence.com/News_214_AFZ Grads.html> [accessed 6 January 2008].

[ZDF News] 2007. “698 Army Recruits Graduate in Magunje.” ZDF News. 20 October 2007.<http://www.zimbabwedefence.com/News_698_recruits_ graduate.html $>$ [accessed 20 October 2007].

[Zimbabwesituation] 2006. “Big Guns Moved to State House.” Zimbabwesituation. 16 June 2006. <http://www.zimbabwesituation.com/jun16b_2006.html\#Z1> [accessed 19 June 2006].

[ZWNEWS] 2005. "Zimbabwe Govt Gets more Arms from China: Taking no Chances.” ZWNEWS [Zimbabwe]. 23 February 2005. <www.zwnews.com/ issuefull.cfm?ArticleID=11290> [accessed 24 February 2005].

[ZWNEWS] 2006. “ ZDF Commander Denies Conflict of Interest Charges.” ZWNEWS. 14 September 2006. <www.zwnews.com/issuefull.cfm?ArticleID= 15136> [accessed 14 September 2006].

\section{Appendix: Research questions}

1. What are the chief arguments used to justify Zimbabwe's level of military expenditure? In your opinion, how valid are they?

2. What do you think are the fundamental factors which determine the level and trend of Zimbabwe's military expenditure?

3. To what extent do you think the military is or should be a special case, which should get most of what it wants in terms of budgetary resources?

4. Are you familiar with Zimbabwe's budgetary decisionmaking process? To what extent are "the rules" being followed with respect to military expenditure?

5. Is there any sense within Cabinet of trade-offs between military expenditure and other government expenditure categories or is each a separate decision?

6. To what extent do pressure groups influence Zimbabwe's military expenditure decisions? Do you have any illustrations of their actions?

7. To what extent do you think beliefs or attitudes held by Zimbabwe's decisionmakers influence the country's level of military expenditure?

8. To what extent do you think that pressures from outside Zimbabwe influence its level of military expenditure?
9. How is national pride or status understood by government decisionmakers?

10. How is security understood by government decisionmakers?

11. How are budgetary allocation decisions made in both technical and political senses?

12. How are new understandings of the role of the military being used in order to maintain military expenditure levels when territorial security is of limited relevance? 13. What are the dynamics of the military pressure group operations in Zimbabwe? 